\title{
Pendugaan Tingkat Produktivitas Pertanian Lahan Kering dengan Metode Indeks Storie di Kecamatan Raya Kabupaten Simalungun
}

\author{
Apong Sandrawati1) dan Arion Euodia Saragih Garingging 2) \\ 1) Staff Pengajar Fakultas Pertanian, Universitas Padjadjaran \\ 2) Alumni Program Studi Agroteknologi, Fakultas Pertanian, Universitas Padjadjaran. \\ Koresponden : apong.sandrawati@unpad.ac.id
}

\begin{abstract}
The aimed of this research was to find out the level of agricultural land productivity at Raya SimalungunSubdistrict with Storie Index Method. This research had been done since March-May 2014 at Raya Simalungun Subdistrict. Sampling spot was done at the certain agricultural landused, slope, and types of soil. Land use types consist of dry land agriculture and plantation. The slopes consisted of land with vary on declivity; 2-15\%, 15-25\%, 25-40\% and $>40 \%$, meanwhile the soil's types include Tropaquepts, Dystrandepts, Haplorthox, Tropudults, Hydrandepts. The result of agriculture land based on several factors; dynamic factor of land such as drainage, erossion, $p H$, Electric Conductivity (EC) of soil layer, showed that the level of productivity of agricultural land in Raya Simalungun Subdistrict is Excellent Quality, Moderate, Poor and Very Poor. The most extensive land quality is at Grade 3 or Medium quality is amounted to 21,109.85 Ha or $88.65 \%$ of the area of dry land agriculture. Area of productive dry land agriculture in Raya Simalungun Subdistrict is 22,059.40 Ha or 92,63\% and less productive land area is 1,754 Ha or 7.37 of area dry land agriculture.
\end{abstract}

Key words: Productivity of agricultural land, storie index, texture, landuse, drainage, erossion, $p H$, Electric Conductivity (EC).

\section{PENDAHULUAN}

Lahan merupakan wadah bagi sumber daya alam yang memiliki sifat strategis bagi pembangunan. Pembangunan sektor fisik seperti sektor pertanian, kehutanan, perumahan, industri, dan transportasi memerlukan lahan. Lahan merupakan bagian dari bentang alam (landscape) yang mencakup pengertian lingkungan fisik termasuk iklim, topografi, tanah, hidrologi, dan bahkan keadaan vegetasi alami (natural vegetation), semua itu secara potensial akan berpengaruh terhadap penggunaan lahan (FAO, 1975 dalam Arsyad, 2006).

Lahan dalam pengertian lebih luas termasuk yang telah dipengaruhi oleh berbagai aktivitas flora, fauna dan manusia baik di masa lalu maupun saat sekarang. Penggunaan lahan yang optimal khususnya sebagai usaha pertanian memerlukan keterkaitan dengan karakteristik dan kualitas lahannya, hal tersebut disebabkan adanya keterbatasan dalam penggunaan lahan sesuai dengan karakteristik dan kualitas lahannya. Oleh karena itu, penggunaan lahan untuk kegiatan pertanian perlu diketahui terlebih dahulu kualitas lahan tersebut sehingga kesesuaian lahan dapat terpenuhi (Foth, 1990)

Manusia dan jenis penggunaan lahan merupakan faktor penting dalam usaha per- tanian yang dapat mempengaruhi sumberdaya lahan. Faktor manusia dapat memberikan dampak positif atau negatif pada suatu lahan, tergantung kepada cara pengelolaan pertanian yang dilakukan. Pengelolaan lahan yang dilakukan oleh manusia pada dasarnya dapat mengancam kelestarian lingkungan.

Kecamatan Raya merupakan kecamatan terluas di Kabupaten Simalungun, Sumatera Utara dengan luas 33.564,16 Ha. Kecamatan Raya merupakan daerah pertanian dengan luas lahan pertaniannya 24.883,40 Ha yang terdiri atas pertanian sawah $1.070 \mathrm{Ha}(3,19$ \%) dan non sawah 23.813,40 Ha (70,95 \%). Kecamatan Raya merupakan areal pertanian yang memiliki potensi besar untuk dikembangkan dan dijadikan sebagai daerah penyuplai kebutuhan pangan.

Perpindahan pusat pemerintahan Kabupaten Simalungun ke Pematang Raya yang merupakan salah satu desa di Kecamatan Raya pada tahun 2008 mengakibatkan peningkatan jumlah penduduk yang pesat. Hal ini diikuti oleh peningkatan kebutuhan akan lahan. Peningkatan jumlah penduduk dan semakin berkembangnya usaha non pertanian menyebabkan adanya tekanan terhadap keberadaan lahan pertanian khususnya pertanian lahan kering di wilayah tersebut, sehingga 
lahan pertanian bergeser fungsinya menjadi pemukiman, perkantoran dan infrastruktur. Pergeseran fungsi lahan juga menyebabkan terjadinya perubahan tenaga kerja dari petani menjadi tenaga kerja di luar sektor pertanian.

Seiring dengan kebutuhan lahan, kebutuhan akan pangan juga semakin meningkat. Ketersediaan lahan yang makin terbatas menjadi pemicu berbagai alih fungsi lahan termasuk perambahan hutan. Perubahan fungsi hutan menjadi tegalan, ladang dan perkebunan tanpa memperhatikan kaidah konservasi. Hal tersebut akan berdampak terhadap penurunan daya dukung lingkungan terhadap pertanian berkelanjutan.

Sistem usaha tani pada lahan kering yang dilakukan tanpa upaya konservasi dapat mengakibatkan sistem pertanian tidak berkelanjutan. Sebagian besar petani belum mempunyai kesadaran akan pentingnya kelestarian dan perlindungan terhadap lahan untuk pertanian yang berkelanjutan. Berbagai tindakan yang dilakukan para petani dan pengelola lahan lainnya, pada prinsipnya dapat mempengaruhi tingkat produktivitas lahan.

Produktivitas lahan pertanian sangat mempengaruhi perekonomian suatu daerah. Semakin menurun produktivitas suatu lahan pertanian maka tingkat pendapatan dari pertanian akan semakin berkurang. Perlu diupayakan usaha menjaga dan meningkatkan produktivitas lahan sehingga perekonomian petani stabil dan meningkat. Oleh karena itu, ketersediaan data baik data tabular maupun data spasial sangat diperlukan untuk mengetahui sistem manajemen yang baik sehingga pengolahan lahan produktif. Pentingnya mengetahui data mengenai tingkat produktivitas lahan pertanian adalah sebagai dasar dalam mengambil keputusan untuk konservasi kualitas lahan.

\section{BAHAN DAN METODE}

Penelitian ini dilaksanakan pada bulan Maret sampai Mei 2014. Pengambilan data lapangan dilakukan di Kecamatan Raya, Kabupaten Simalungun. Analisis laboratorium dilaksanakan di laboratorium fisika tanah, laboratorium kesuburan tanah dan nutrisi tanaman, serta laboratorium evaluasi lahan, Departemen Ilmu Tanah dan Sumberdaya Lahan Fakultas Pertanian Universitas Padjadjaran.

Bahan yang digunakan meliputi peta dasar dan peta tematik, yaitu:
- Peta struktur ruang Kecamatan Raya Kabupaten Simalungun skala 1: 50.000

- Peta penggunaan lahan skala 1: 50.000

- Peta Kemiringan Lereng skala 1: 50.000

- Peta Tanah skala 1: 50.000

Sumber data lainnya yang digunakan adalah data curah hujan lokasi penelitian periode tahun 2004 - 2013. Bahan lainnya meliputi bahan kimia yang digunakan untuk analisis sifat tanah di laboratorium.

Peralatan yang digunakan dalam penelitian ini meliputi peralatan kerja lapangan, laboratorium dan studio. Peralatan kerja lapangan meliputi: bor tanah, meteran, klinometer, Global Positioning System (GPS), cangkul, kantong plastik, kamera, pisau, alat tulis, dan kertas label. Peralatan laboratorium meliputi timbangan analitik, oven, dan alatalat gelas. Peralatan studio terdiri dari perangkat keras (hardware) dan perangkat lunak (software) yaitu Arc.GIS 9.3 dan microsoft office.

Tahap pertama kegiatan penelitian adalah melakukan persiapan. Kegiatan persiapan meliputi: studi literatur, penyusunan peta kerja yang meliputi pembentukkan peta satu-an lahan melalui proses overlay peta kemiringan lereng, peta tanah, dan peta pengunaan lahan dilakukan dengan bantuan software ArcGIS. Penentuan lokasi sampling dilakukan berdasarkan sebaran satuan lahan, setiap satu satuan lahan diwakili oleh satu titik sampel. Letak titik sampel pada satu satuan lahan ditentukan berdasarkan pertimbangan: kekomplekan lahan, luas areal satuan lahan, dan kemudahan pencapaian lokasi.

Kegiatan survey utama dilakukan untuk mengamati kondisi di lapangan dan pengambilan contoh tanah. Pengamatan lapangan dilakukan dengan mengamati parameter-parameter pada setiap sampling unit. Parameter yang diamati di lapangan meliputi: kemiringan lereng, drainase, erosi aktual, jenis penggunaan lahan, jenis vegetasi, dan pengelolaan lahan (pola tanam, pengolahan lahan, serta konservasi tanah dan air).

Contoh tanah yang diambil adalah contoh tanah terganggu. Pengambilan contoh tanah dilakukan dengan boring sampai kedalaman $60 \mathrm{~cm}$. Parameter yang dianalisis di laboratorium meliputi: tekstur, $\mathrm{pH}$, dan kondiktivitas listrik (DHL). Tekstur dianalisis dengan metode pipet, sedangkan $\mathrm{pH}$ dan DHL dianalisis melalui metode potensiometri. 
Analisis data dilakukan dengan pemberian nilai bobot, perhitungan persentase nilai bobot dan pengkelasan tingkat produktivitas lahan. Nilai bobot menggambarkan besarnya pengaruh parameter terhadap produktivitas lahan. Nilai bobot ditentukan berdasarkan indeks storie yang telah dimodifikasi oleh O'geen et. al. (2008). Penentuan nilai bobot kemiringan lereng berdasarkan pengaruhnya terhadap produktivitas lahan dapat dilihat pada Tabel 1.

Tabel 1 Klasifikasi dan Nilai Bobot Kemiringan Lereng Lahan

\begin{tabular}{lcc}
\hline Kelas Lereng & Simbol Kelas & Nilai Bobot (\%) \\
\hline $0-3 \%$ & KL1 & 100 \\
$4-8 \%$ & KL2 & 95 \\
$9-15 \%$ & KL3 & 90 \\
$16-30 \%$ & KL4 & 85 \\
$30-45 \%$ & KL5 & 70 \\
$>45 \%$ & KL6 & 50 \\
\hline \multicolumn{2}{l}{ Sumber: O'geen et al $(2008)$}
\end{tabular}

Sumber: O'geen et al (2008)

Pemberian nilai bobot drainase berdasarkan tingkat pengaruhnya terhadap produktivitas lahan dapat dilihat pada Tabel 2.

Tabel 2 Klasifikasi dan Nilai Bobot Drainase Tanah

\begin{tabular}{lcc}
\hline \multicolumn{1}{c}{ Kelas Drainase } & $\begin{array}{c}\text { Simbol } \\
\text { Kelas }\end{array}$ & $\begin{array}{c}\text { Nilai Bobot } \\
(\%)\end{array}$ \\
\hline Baik & SKD1 & 100 \\
Agak baik & SKD2 & 90 \\
Cepat dan agak cepat & SKD3 & 85 \\
Agak terhambat & SKD4 & 70 \\
$\begin{array}{l}\text { Terhambat dan sangat } \\
\text { terhambat }\end{array}$ & SKD5 & 50 \\
\hline
\end{tabular}

Sumber: O'geen et al (2008)

Pemberian nilai bobot $\mathrm{pH}$ berdasarkan tingkat pengaruhnya terhadap produktivitas lahan dapat dilihat pada Tabel 3.

Tabel 3 Klasifikasi dan Nilai Bobot pH Tanah

\begin{tabular}{lcc}
\hline \multicolumn{1}{c}{ Kelas pH } & Simbol Kelas & $\begin{array}{c}\text { Nilai Bobot } \\
(\%)\end{array}$ \\
\hline $5,5-8,5$ & SKH1 & 100 \\
$5-5,4 ; 8,6-9$ & SKH2 & 75 \\
$4,5-4,9 ; 9,1-9,5$ & SKH3 & 50 \\
$3,6-4,4 ; 9,6-9,9$ & SKH4 & 25 \\
$<3,5 ;>10$ & SKH4 & 0 \\
\hline Sumber: 0'geen et al (2008)
\end{tabular}

Pemberian nilai bobot DHL berdasarkan tingkat pengaruhnya terhadap produktivitas lahan dapat dilihat pada Tabel 4.

Tabel 4 Klasifikasi dan Nilai Bobot DHL Tanah

\begin{tabular}{lcc}
\hline Kelas DHL & Simbol Kelas & Nilai Bobot (\%) \\
\hline$<1 \mathrm{dS} / \mathrm{m}$ & SKC1 & 100 \\
$1-2 \mathrm{dS} / \mathrm{m}$ & SKC2 & 99 \\
$2-3 \mathrm{dS} / \mathrm{m}$ & SKC3 & 98 \\
$3-4 \mathrm{dS} / \mathrm{m}$ & SKC4 & 95 \\
$4-5 \mathrm{dS} / \mathrm{m}$ & SKC5 & 87 \\
$5-10 \mathrm{dS} / \mathrm{m}$ & SKC6 & 60 \\
$10-15 \mathrm{dS} / \mathrm{m}$ & SKC7 & 40 \\
\hline Sumber: 0'geen etal $(2008)$ &
\end{tabular}

Sumber: O'geen et al (2008)

Penentuan nilai bobot tekstur berdasarkan tingkat pengaruhnya terhadap produktivitas lahan dapat dilihat pada Tabel 5.

Tabel 5 Klasifikasi dan Nilai Bobot Tekstur Tanah

\begin{tabular}{|c|c|c|}
\hline Tekstur & $\begin{array}{c}\text { Simbol } \\
\text { Kelas }\end{array}$ & $\begin{array}{c}\text { Nilai } \\
\text { Bobot } \\
(\%)\end{array}$ \\
\hline $\begin{array}{l}\text { Lempung berpasir sangat halus, } \\
\text { Lempung berpasir halus, lem- } \\
\text { pung, debu, lempung berdebu }\end{array}$ & KT1 & 100 \\
\hline $\begin{array}{l}\text { Liat berpasir sangat halus, lem- } \\
\text { pung berpasir, lempung liat } \\
\text { berpasir, lempung berliat, ber- } \\
\text { kapur lempung liat berdebu }\end{array}$ & KT2 & 95 \\
\hline $\begin{array}{l}\text { Lempung berpasir kasar, liat } \\
\text { berpasir halus, tidak berkapur } \\
\text { lempung liat berdebu, lempung } \\
\text { berliat }\end{array}$ & KT3 & 90 \\
\hline Liat berpasir, pasir sangat halus & KT4 & 80 \\
\hline $\begin{array}{l}\text { Pasir halus, liat berpasir kasar, } \\
\text { liat berpasir }\end{array}$ & KT5 & 65 \\
\hline Pasir, liat berdebu & KT6 & 60 \\
\hline Liat & KT7 & 50 \\
\hline Pasir kasar & KT8 & 30 \\
\hline
\end{tabular}

Tingkat erosi pada suatu lahan sangat diperhitungkan dalam pendugaan tingkat produktivitas lahan. Pemberian nilai bobot kelas erosi berdasarkan tingkat pengaruhnya terhadap produktivitas lahan dapat dilihat pada Tabel 6. Perhitungan besarnya erosi dlakukan melalui pendekatan Universal Soil Loss Equation (USLE). 
Tabel 6 Klasifikasi dan Nilai Bobot Tingkat Erosi

\begin{tabular}{lcc}
\hline Tingkat Erosi & Simbol Kelas & Nilai Bobot (\%) \\
\hline Sangat ringan & SKE1 & 100 \\
Ringan & SKE2 & 80 \\
Sedang & SKE3 & 60 \\
Berat & SKT4 & 40 \\
Sangat berat & SKE5 & 20 \\
\hline \multicolumn{2}{l}{ Sumber: O'geen et al $(2008)$}
\end{tabular}

Perhitungan persentase nilai bobot dilakukan dengan sistem perkalian berbagai faktor yaitu: faktor tekstur, faktor kemiringan lereng dan faktor sifat dinamis. Persentase faktor dinamis (KS) dihasilkan dari perkalian subfak-tor kimia dan kesuburan $\left(\mathrm{X}_{\mathrm{cf}}\right)$ dengan subfak-tor kondisi hidrologi dan fisika $\left(\mathrm{X}_{\mathrm{hp}}\right)$. Sub-faktor kimia dan kesuburan ( $\left.\mathrm{X}_{\mathrm{cf}}\right)$ diperoleh dengan merata-ratakan jumlah bobot $\mathrm{pH}$ dan DHL (persamaan 1).

$$
\mathrm{X}_{\mathrm{cf}}=\frac{\mathrm{SKH}+\mathrm{SKC}}{2}
$$

Subfaktor hidrologi dan fisika ( $\left.\mathrm{X}_{\mathrm{hp}}\right)$ meliputi drainase dan kelas erosi. Nilai $X_{h p}$ diperoleh dari rata-rata jumlah nilai bobot drainase dan kelas erosi (Persamaan 2).

$$
\mathrm{X}_{\mathrm{hp}}=\frac{\text { SKE }+ \text { SKD }}{2} \text {. }
$$

Persentase faktor dinamis (KS) diperoleh dari hasil perkalian $\mathrm{X}_{\mathrm{cf}}$ dan $\mathrm{X}_{\mathrm{hp}}$ (Persamaan 3).

$$
\mathrm{KS}=\mathrm{X}_{\mathrm{cf}} \times \mathrm{X}_{\mathrm{hp}}
$$

Perhitungan Storie Indeks Rating (SIR) diperoleh dari persamaan (4) yaitu hasil perkalian nilai bobot faktor tekstur (KT), faktor lereng (KL), dan factor dinamis (KS) (Storie, 1944 dalam Hardjowigeno dan Widiatmaka, 2007).

$$
\mathrm{SIR}=\mathrm{KT} \times \mathrm{KL} \times \mathrm{KS}
$$

Nilai akhir perhitungan (SIR) digunakan untuk memperoleh pendugaan kelas produktivitas lahan. Tingkat produktivitas lahan dikelompokkan menjadi 6 kelas (Tabel 7).

Hasil akhir penelitian ini berupa peta sebaran tingkat produktivitas lahan pertanian di Kecamatan Raya Kabupaten Simalungun. Peta disajikan pada skala 1: 100.000 . Selain peta, hasil penelitian juga disajikan dalam laporan yang berisi pembahasan mengenai perbedaan tingkat produktivitas lahan perta-

\begin{tabular}{|c|c|c|}
\hline Kelas & $\begin{array}{l}\text { Kualitas } \\
\text { Lahan }\end{array}$ & Keterangan \\
\hline 1. & $\begin{array}{c}\text { Baik } \\
\text { Sekali }\end{array}$ & $\begin{array}{l}\text { Tanah-tanah yang mempu- } \\
\text { nyai nilai } 80-100 \% \text { dan cocok } \\
\text { untuk penggunaan yang luas, } \\
\text { meliputi alfalfa, buah-buahan } \\
\text { dan field crops. }\end{array}$ \\
\hline 2. & Baik & $\begin{array}{l}\text { Tanah-tanah yang mempu- } \\
\text { nyai nilai } 60-79 \% \text {, cocok un- } \\
\text { tuk sebagian besar tanaman. } \\
\text { Hasil umumnya baik hingga } \\
\text { baik sekali. }\end{array}$ \\
\hline 3. & Sedang & Tanah-tanah yang mempu- \\
\hline
\end{tabular}
nian di lokasi penelitian.
Tabel 7 Klasifikasi Tingkat Produktivitas Lahan nyai nilai 40-59\%, umumnya mempunyai kualitas sedang, dengan kisaran penggunaan atau kesesuaian lebih sempit daripada kelas 1 dan kelas 2 . Tanah dalam kelas ini mungkin dapat memberikan hasil yang baik untuk tanaman tertentu.

4. Miskin Tanah-tanah yang mempunyai nilai $20-39 \%$ dan mempunyai kemungkinan penggunaan untuk pertanian yang terbatas. Sebagai contoh: tanah yang termasuk kelas ini mungkin baik untuk padi tetapi kurang baik untuk penggunaan lainnya.

5. Sangat Tanah yang mempunyai nilai miskin 10-19\% dengan kemungkinan penggunaan yang sangat terbatas kecuali untuk padang rumput, karena kondisikondisi yang membatasi, seperti kedangkalan tanah.

6. Bukan Tanah yang mempunyai nilai untuk kurang dari $10 \%$. Sebagai pertanian contoh tanah pasang surut; tanah dengan kadar basabasa tinggi; dan tanah dengan lereng yang curam.

Sumber: Hardjowigeno dan Widiatmaka (2007)

\section{HASIL DAN PEMBAHASAN}

\subsection{Kondisi Umum Daerah Penelitian}

Kecamatan Raya, Kabupaten Simalungun, Sumatera Utara. Kecamatan Raya merupakan kecamatan terluas di Kabupaten Simalungun. Kecamatan Raya terletak pada 02052'-03030' LU dan 98045'-98057' BT. Terletak pada ketinggian tempat 251-1.400 meter di atas permukaan laut. Secara administratif batas wilayah Kecamatan Raya adalah Kecamatan Raya Kahean dan Kecamatan Silou Kahean (utara), Kecamatan Dolog Pardameian (selatan), Keca- 
matan Panombeian Pane (timur) dan sebelah barat berbatasan Kecamatan Purba dan Kecamatan Dolok Silou (Gambar 1).

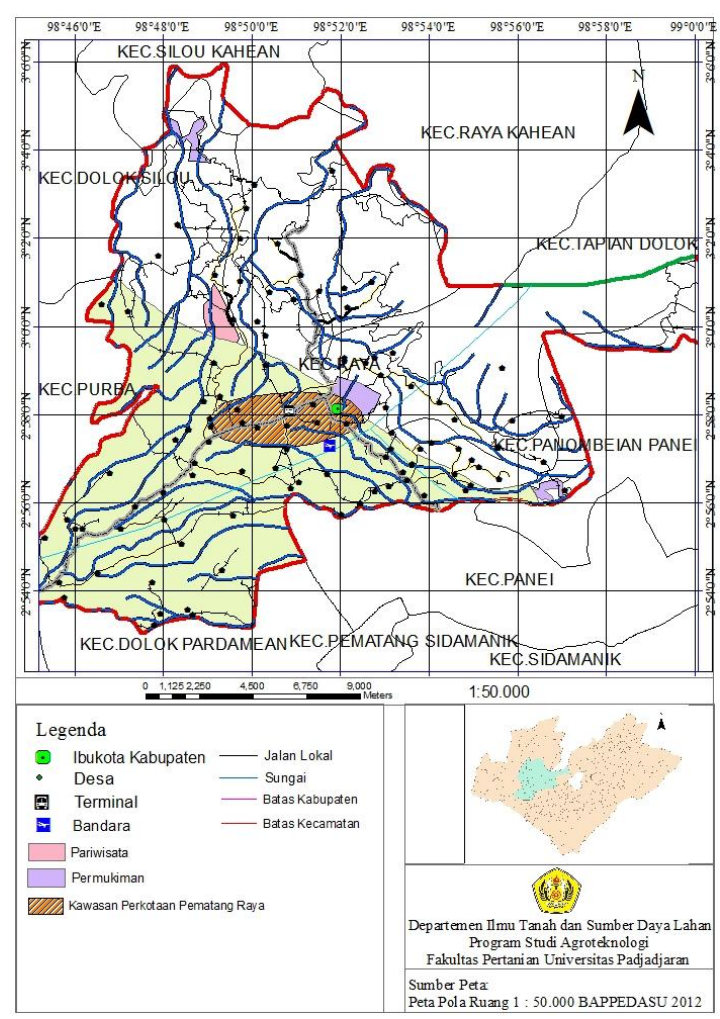

Gambar 1 Lokasi Penelitian: Kecamatan Raya Kabupaten Simalungun

Berdasarkan data curah 10 tahun terakhir (tahun 2004-2013) yang diperoleh dari Stasiun Curah Hujan Sidamanik (stasiun terdekat), Kecamatan Raya memiliki curah hujan 1977 - $3190 \mathrm{~mm} /$ tahun (rata-rata 2810 $\mathrm{mm} /$ tahun). Perbedaan bulan basah dan kering sangat menyolok yaitu 10,8 bulan basah per tahun dan hanya 0,5 bulan kering per tahun. Tipe iklim Kecamatan Raya menurut sistem klasifikasi Schmidt dan Fergusson termasuk ke dalam Tipe A (sangat basah).

Topografi lahan pertanian Kecamatan Raya didominasi oleh datar sampai berombak (kemiringan lereng < 15\%) seluas 22.453,05 Ha $(66,89 \%)$. Kelas topografi lainnya yaitu bergelombang (kemiringan lereng 15-25\%) dengan luas $1.998,64 \mathrm{Ha}(5,95 \%)$. Topografi berbukit (kemiringan le-reng 25-40 \%) seluas $1.396,26$ Ha $(4,15 \%)$ dan topografi bergunung (kemiringan lereng $>40 \%$ ) seluas $678,05 \mathrm{Ha}$ dengan persentase luas terkecil sebesar 2,02\%.

Penggunaan lahan di Kecamatan Raya, Kabupaten Simalungun didominasi oleh penggunaan lahan untuk pertanian lahan kering.
Pertanian lahan basah di Kecamatan Raya hanya berada pada topografi datar dan berombak dengan kemiringan 2-15\%. Luas pertanian lahan kering di Kecamatan Raya, Kabupaten Simalungun yaitu 21.820,71 Ha atau 65,01 $\%$ dari total luas wilayah Kecamatan Raya.

Berdasarkan peta tanah, di daerah penelitian dapat diklasifikasikan ke dalam 5 (lima) sub group tanah, yaitu: Typic Tropaquepts, Typic Hydrandepts, Typic Tropudults, Typic Haplorthox dan Typic Dystrandepts. Jenis tanah yang paling dominan adalah Typic Tropudults dengan total luas 9.301,42 $\mathrm{Ha}$ $(28,03 \%)$.

\subsection{Karakteristik Tanah dan Nilai Bobot}

Analisis terhadap karakteristik tanah dilakukan terhadap masing-masing satuan lahan. Terdapat 21 satuan lahan yang dianalisis. Karakteristik masing-masing satuan lahan tersebut dapat dilihat pada Tabel 8.

Tabel 8 Karakteristik Satuan Lahan di Lokasi Penelitian

\begin{tabular}{cl}
\hline Unit & \multicolumn{1}{c}{ Keterangan Satuan Lahan } \\
\hline A & Perkebunan;Dystrandepts; 2-15\% \\
B & Perkebunan; Haplorthox; 2-15\% \\
C & Perkebunan; Tropudults; 2-15\% \\
D & Pertanian lahan kering; Dystrandepts; 2-15\% \\
E & Pertanian lahan kering;Dystrandepts; $15-25 \%$ \\
F & Pertanian lahan kering;Dystrandepts; 25-40\% \\
G & Pertanian lahan kering; Dystrandepts; > 40\% \\
H & Pertanian lahan kering; Haplorthox; 2-15\% \\
I & Pertanian lahan kering, Haplorthox, 15-25\% \\
J & Pertanian lahan kering, Haplorthox, 25-40\% \\
K & Pertanian lahan kering, Haplorthox, > 40\% \\
L & Pertanian lahan kering, Hydrandepts, 2-15\% \\
M & Pertanian lahan kering, Hydrandepts, 15-25\% \\
N & Pertanian lahan kering, Hydrandepts, 25-40\% \\
O & Pertanian lahan kering, Hydrandepts, > 40\% \\
P & Pertanian lahan kering, Tropaquepts, 2-15\% \\
Q & Pertanian lahan kering, Tropaquepts, 15-25\% \\
R & Pertanian lahan kering, Tropudults, 2-15\% \\
S & Pertanian lahan kering, Tropudults, 15-25\% \\
T & Pertanian lahan kering, Tropudults, 25-40\% \\
U & Pertanian lahan kering, Tropudults, > 40\% \\
\hline
\end{tabular}

Data karakteristik tanah merupakan hasil analisis laboratorium. Hasil analisis terhadap karakteristik tanah dan nilai pembobotan masing-masing karak-teristik pada setiap unit lahan dapat dilihat pada Tabel 9. 
Tabel 9 Hasil Analisis terhadap Karakteristik Tanah dan Penilaian Bobot (\%) Berdasarkan Indeks Storie (modifikasi O'geen et. al., 2008)

\begin{tabular}{|c|c|c|c|c|c|c|c|c|c|c|c|c|}
\hline \multirow[b]{2}{*}{ Unit } & \multicolumn{2}{|l|}{ Tekstur } & \multicolumn{2}{|c|}{ Kemiringan } & \multicolumn{2}{|c|}{ Drainase } & \multicolumn{2}{|c|}{ Erosi } & \multicolumn{2}{|c|}{$\mathrm{pH} \mathrm{H} \mathrm{H}_{2} \mathrm{O}$} & \multicolumn{2}{|c|}{ DHL } \\
\hline & Kelas & $\begin{array}{c}\text { Bobot } \\
(\%)\end{array}$ & $\begin{array}{c}\text { Slope } \\
(\%)\end{array}$ & $\begin{array}{c}\text { Bobot } \\
(\%)\end{array}$ & Kelas & $\begin{array}{c}\text { Bobot } \\
(\%)\end{array}$ & Kelas*) & $\begin{array}{c}\text { Bobot } \\
(\%)\end{array}$ & Nilai & $\begin{array}{c}\text { Bobot } \\
(\%)\end{array}$ & $\begin{array}{c}\text { Nilai } \\
(\mathrm{dS} / \mathrm{m})\end{array}$ & $\begin{array}{c}\text { Bobot } \\
(\%)\end{array}$ \\
\hline A & Lempung berliat & 95 & 12 & 90 & Baik & 100 & $\mathrm{R}$ & 80 & 4,8 & 50 & 0,72 & 100 \\
\hline B & Lempung berliat & 95 & 3 & 100 & Baik & 100 & SR & 100 & 5,2 & 75 & 1,10 & 99 \\
\hline $\mathrm{C}$ & Liat & 50 & 6 & 95 & Baik & 100 & $\mathrm{R}$ & 80 & 6,7 & 100 & 1,75 & 99 \\
\hline $\mathrm{D}$ & Lempung berliat & 95 & 13 & 90 & Agak baik & 90 & $\mathrm{R}$ & 80 & 4,5 & 50 & 8,49 & 60 \\
\hline$E$ & Lempung & 100 & 21 & 85 & Agak baik & 90 & $\mathrm{~S}$ & 60 & 4,4 & 25 & 0,61 & 100 \\
\hline $\mathrm{F}$ & Lempung berpasir & 95 & 33 & 70 & Agak baik & 90 & SB & 20 & 4,4 & 25 & 2,65 & 98 \\
\hline G & Lempung berliat & 95 & 47 & 50 & Baik & 100 & $S$ & 60 & 4,6 & 50 & 1,18 & 99 \\
\hline $\mathrm{H}$ & Lempung berliat & 95 & 14 & 90 & Baik & 100 & $\mathrm{~S}$ & 60 & 4,8 & 50 & 0,90 & 100 \\
\hline I & Liat berdebu & 60 & 21 & 85 & Agak baik & 90 & SB & 20 & 5,1 & 75 & 1,28 & 99 \\
\hline $\mathrm{J}$ & Lempung berliat & 95 & 28 & 85 & Agak baik & 90 & $\mathrm{~S}$ & 60 & 5,0 & 75 & 1,57 & 99 \\
\hline $\mathrm{K}$ & Liat & 50 & 42 & 70 & Baik & 100 & B & 40 & 4,6 & 50 & 0,89 & 100 \\
\hline $\mathrm{L}$ & Lempung & 100 & 14 & 90 & Agak baik & 90 & $\mathrm{~B}$ & 40 & 4,9 & 50 & 1,21 & 99 \\
\hline $\mathrm{M}$ & Lempung berliat & 95 & 21 & 85 & Baik & 100 & $\mathrm{~S}$ & 60 & 5,0 & 75 & 0,75 & 100 \\
\hline $\mathrm{N}$ & Lempung berliat & 95 & 31 & 70 & Baik & 100 & SB & 20 & 5,7 & 100 & 1,89 & 99 \\
\hline 0 & Lempung & 100 & 46 & 50 & Agak baik & 90 & SB & 20 & 4,6 & 50 & 0,68 & 100 \\
\hline $\mathrm{P}$ & Lempug berpasir & 95 & 9 & 90 & Baik & 100 & $\mathrm{~S}$ & 60 & 4,7 & 50 & 1,21 & 99 \\
\hline$Q$ & Lempung berliat & 95 & 22 & 85 & Agak baik & 90 & SB & 20 & 4,8 & 50 & 0,35 & 100 \\
\hline $\mathrm{R}$ & Lempung berpasir & 95 & 9 & 90 & Baik & 100 & $\mathrm{R}$ & 68 & 4,8 & 50 & 5,02 & 60 \\
\hline$S$ & Lempung berdebu & 100 & 16 & 85 & Baik & 100 & $\mathrm{~B}$ & 40 & 6,3 & 100 & 0,45 & 100 \\
\hline $\mathrm{T}$ & Lempung liat berdebu & 90 & 29 & 85 & Agak baik & 90 & $\mathrm{~B}$ & 40 & 4,5 & 50 & 0,34 & 100 \\
\hline $\mathrm{U}$ & Liat berdebu & 60 & 42 & 70 & Agak baik & 90 & $\mathrm{~S}$ & 60 & 4,8 & 50 & 0,56 & 100 \\
\hline
\end{tabular}

${ }^{*}$ Keterangan Kelas Erosi; SR= Sangat Rendah; R= Rendah; S= Sedang; B= Berat; dan SB=Sangat Berat

\subsection{Penilaian Tingkat Produktivitas Lahan}

Hasil penilaian terhadap tingkat produktivitas yang dihitung berdasarkan persamaanpersamaan Storie Indeks Rating (SIR) dapat dilihat pada Tabel 10. Nilai tertinggi dan terendah pada masing-masing faktor dan subfaktor tidak mutlak menentukan penilaian produktivitas lahan. Kualitas lahan pertanian di Kecamatan Raya berada pada kualitas sangat baik (1), baik (2), sedang (3), miskin (4) dan sangat miskin (5).

Kualitas lahan pertanian yang sangat baik hanya terdapat pada 1 unit lahan yaitu pada unit lahan B (perkebunan; Haplorthox; 2$15 \%$ ) dengan nilai SIR sebesar 82,65\%. Unit lahan B dinilai cocok untuk penggunaan yang luas, meliputi alfalfa, buah-buahan dan field crops. Berdasarkan hasil survey lapangan, unit lahan B sebagian meru-pakan perkebunan dengan vegetasi utama tanaman kopi arabika (Coffee 28rabica L.) yang dibudidayakan secara monokultur. Kopi arabika yang ditanam diwilayah ini dikenal dengan kopi simalungun. Berdasarkan nilai produktivitas lahannya, diharapkan produktivitas kopi ini tergolong tinggi dan menjadi komoditas unggulan wilayah setempat.
Tabel 10 Hasil Penilaian Tingkat Produktivitas Lahan di Lokasi Penelitian

\begin{tabular}{cccccc}
\hline $\begin{array}{c}\text { Unit } \\
\text { Lahan }\end{array}$ & KT & KL & KS & $\begin{array}{c}\text { SIR } \\
(\%)\end{array}$ & $\begin{array}{c}\text { Kelas } \\
\text { Produktivitas }\end{array}$ \\
\hline A & 0,95 & 0,90 & 0,68 & 58,14 & 3 \\
B & 0,95 & 1,00 & 0,87 & 82,65 & 1 \\
C & 0,50 & 0,95 & 0,90 & 42,75 & 3 \\
D & 0,95 & 0,90 & 0,47 & 40,19 & 3 \\
E & 1,00 & 0,85 & 0,47 & 39,95 & 3 \\
F & 0,95 & 0,70 & 0,34 & 22,61 & 4 \\
G & 0,95 & 0,50 & 0,60 & 28,50 & 4 \\
H & 0,95 & 0,90 & 0,60 & 51,30 & 3 \\
I & 0,6 & 0,85 & 0,48 & 24,48 & 4 \\
J & 0,95 & 0,85 & 0,65 & 52,49 & 3 \\
K & 0,5 & 0,70 & 0,53 & 18,55 & 5 \\
L & 1,00 & 0,90 & 0,48 & 43,20 & 3 \\
M & 0,95 & 0,85 & 0,70 & 56,53 & 3 \\
N & 0,95 & 0,70 & 0,60 & 39,90 & 3 \\
O & 1,00 & 0,50 & 0,41 & 20,50 & 4 \\
P & 0,95 & 0,90 & 0,60 & 51,30 & 3 \\
Q & 0,95 & 0,85 & 0,41 & 33,11 & 4 \\
R & 0,95 & 0,90 & 0,50 & 42,75 & 3 \\
S & 1,00 & 0,85 & 0,70 & 59,50 & 3 \\
T & 0,90 & 0,85 & 0,49 & 37,49 & 4 \\
U & 0,60 & 0,70 & 0,56 & 23,52 & 4 \\
\hline
\end{tabular}


Lahan pertanian Kecamatan Raya yang mempunyai kualitas yang paling buruk terdapat pada unit lahan $\mathrm{K}$ dengan nilai SIR $18,55 \%$. Lahan ini berada pada kelas 5 (sangat miskin). Berdasarkan karakteristik satuan lahannya, unit lahan $\mathrm{K}$ (pertanian lahan kering, Haplorthox, > 40\%) secara alami dapat dikategorikan memiliki tingkat kesuburan yang rendah. Faktor utama adalah sifat tanah yang termasuk Oxisol yang merupakan tanah-tanah tua dengan mineral liat utama berupa oksida dan memiliki KTK yang rendah (Hardjowigeno, 2010).

Tanah-tanah Oxisol dinilai mempunyai tingkat kesuburan yang rendah. Rendahnya tingkat kesuburan tanah dapat dilihat dari nilai $\mathrm{pH}$ tanah tergolong masam $(4,6)$. Faktor lain yang mempengaruhi rendah-nya nilai produktivitas lahan pada unit lahan $\mathrm{K}$ adalah kemiringan. Berdasarkan hasil pengukuran di lapangan nilai kemiringan lereng mencapai 42 $\%$ sehingga nilai bobot pada faktor kemiringan sangat kecil.

\subsection{Peta Sebaran Lahan Berdasarkan Produktivitas Lahan}

Berdasarkan hasil penailaian produktivitas lahan pada masing-masing unit lahan, maka dapat disusun peta sebaran lahan ber- dasarkan nilai produktivitas lahannya. Berdasarkan luasaannya, produktivitas lahan kelas 3 (sedang) menyebar dengan luasan tertinggi dengan proporsi luasan $88,65 \%$ dari total luas area penelitian. Kelas produktivitas lahan dengan luasan terendah adalah kelas 5 (sangat miskin) dengan proporsi luasan 0,28 $\%$ dari total luas area penelitian (Tabel 11).

Tabel 11 Luasan Lahan Berdasarkan Kelas Produktivitas Lahan di Kecamatan Raya

\begin{tabular}{ccrr}
\hline \multirow{2}{*}{$\begin{array}{c}\text { Kelas } \\
\text { Lahan }\end{array}$} & \multirow{2}{*}{ Kualitas Lahan } & \multicolumn{2}{c}{ Luasan } \\
\cline { 3 - 4 } & & Hektar & Persen \\
\hline 1 & Sangat baik & 949,56 & 3,99 \\
2 & Baik & 0 & 0 \\
3 & Sedang & $21.109,85$ & 88,65 \\
4 & Miskin & $1.687,89$ & 7,09 \\
5 & Sangat miskin & 66,11 & 0,28 \\
6 & Bukan untuk & 0 & 0 \\
& pertanian & 0 & \\
\hline & Jumlah & $23.813,40$ & 100,00 \\
\hline
\end{tabular}

Sebaran lahan berdasarkan kelas lahan dan penilaian produktivitas lahan di Kecamatan Raya Kabupaten Simalungun dapat dilihat pada Gambar 2.

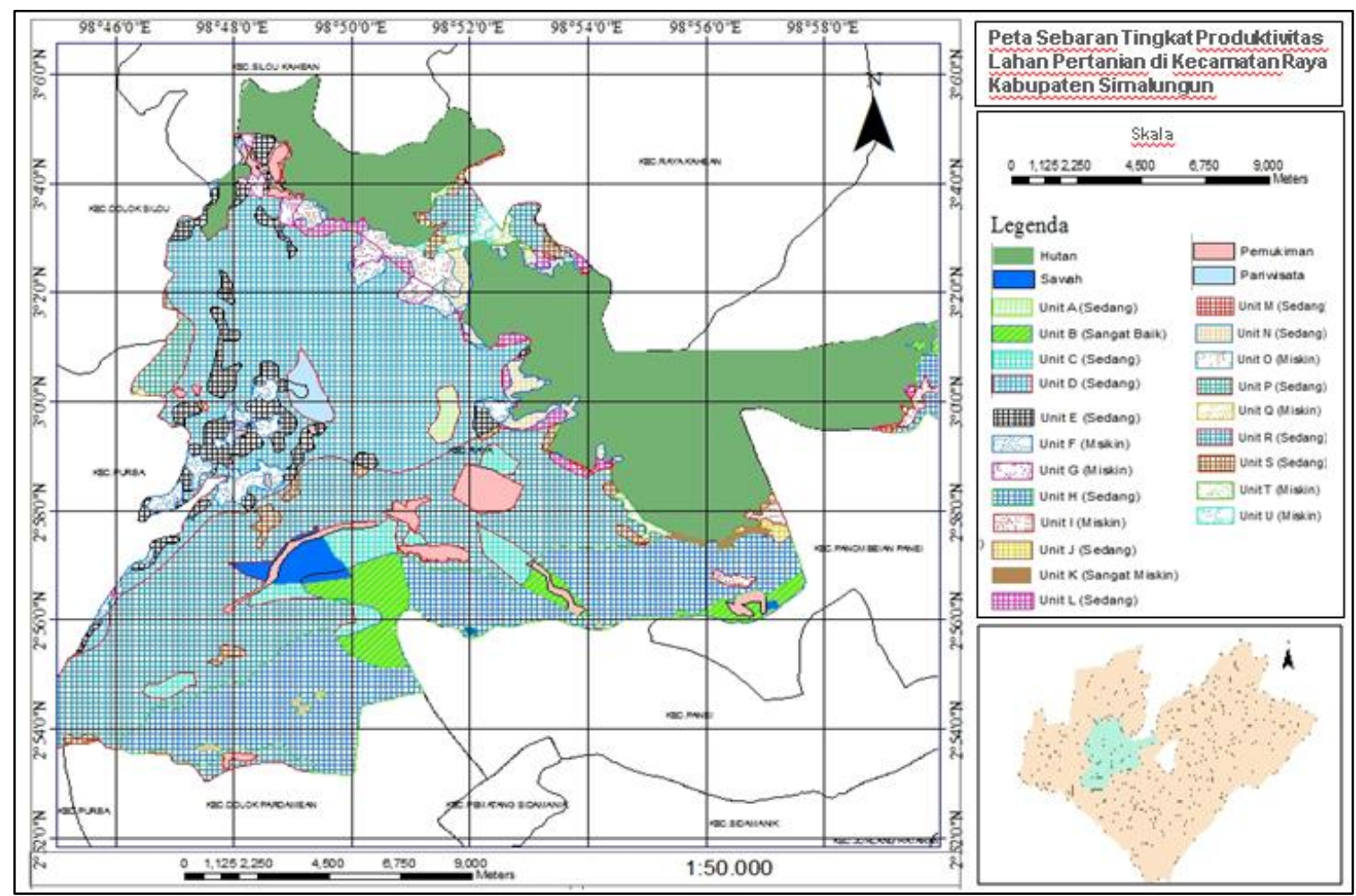

Gambar 2 Peta Sebaran Tingkat Produktivitas Lahan Pertanian Kecamatan Raya Kabupaten Simalungun 


\section{SIMPULAN}

Tingkat produktivitas pertanian lahan kering di Kecamatan Raya Kabupaten Simalungun berada pada kualitas sangat baik, sedang, miskin dan sangat miskin. Tingkat produktivitas pertanian lahan kering di Kecamatan Raya Kabupaten Simalungun yang paling luas berada pada kelas 3 (kualitas tanah sedang) yaitu 21.109,85 Ha atau sebesar $88,65 \%$ dari luas lahan pertanian lahan kering di Kecamatan Raya.

Luas pertanian lahan kering yang produktif di Kecamatan Raya Kabupaten Simalungun yaitu 22.059,40 Ha atau 92,63\% dan luas lahan kurang produktif yaitu 1.754 Ha atau 7,37 \% dari total luas lahan pertanian kering.

\section{DAFTAR PUSTAKA}

Arsyad, S. 2006. Konservasi Tanah dan Air. Institut Pertanian Bogor Press, Bogor.

Foth, H.D. 1990. Fundamental of Soil Science. Jhon Wiley \& Sons. New York.

Hardjowigeno, S. dan Widiatmaka. 2007. Kesesuaian Lahan dan Perencanaan Tataguna Tanah. UGM Press. Yogyakarta.

Hardjowigeno, S. 2010. Ilmu Tanah. Akademika Pressindo. Jakarta.

O'geen A.T., Susan B. and Randal J. 2008. A Revised Storie Index for Use with Digital Soils Information. Division of Agriculture and Natural Resources. University of California. Paper. 